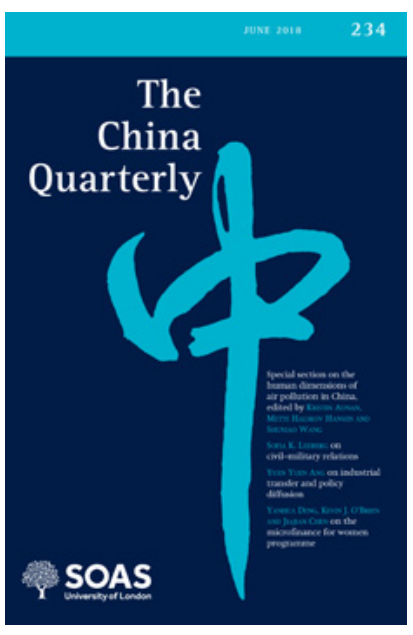

The China Quarterly published by Cambridge University Press.
In August 2017.

Cambridge University

Press (CUP) removed

over three hundred

articles published in

The China Quarterly

from its Chinese

website. The articles

had been chosen for

censorship by very

haphazard searches

based on 'sensitive'

keywords.

\section{China Studies between Censorship and Self- censorship}

\section{Kevin Carrico}

$t$ has not been a very auspicious year for freedom of expression in China Studies.

In August 2017, Cambridge University Press (CUP) removed over three hundred articles published in The China Quarterly from its Chinese website. The articles had been chosen for censorship by very haphazard searches based on 'sensitive' keywords: Tiananmen, Cultural Revolution, Taiwan, Tibet. After a rare vocal backlash, CUP reversed its decision.

Just a few months later in November, news broke that Springer Nature had done the same. Unlike Cambridge, Springer cravenly stood by its decision to censor as a matter of complying with 'local distribution laws', ironically portraying its two-tier system granting China-based scholars second-class access as a matter of maintaining access.

A few weeks later, publisher Allen \& Unwin notified Clive Hamilton that it would not be publishing his book Silent Invasion: China's Influence in Australia due to fears of 'a vexatious defamation action' from Beijing's supporters and enablers. Ironically, the decision to back out from publishing the book proved Hamilton's thesis alleging inordinate Partystate influence in contemporary Australia: this would appear to be the first time that a book was banned overseas for crossing Beijing's red lines.

Finally, in April 2018, South China Morning Post broke the news that a special issue of The China Quarterly had fallen apart due to self-censorship. Two academics based in Europe contributing to a special issue on China's West became concerned about publishing their papers alongside James Leibold's study of state surveillance in Xinjiang. Withdrawing their papers for fear of offending Beijing, the issue fell apart.

As academics, we experience pressures, both direct and indirect, from the Party-state, all too often abetted by publishers and universities eager to sacrifice principles to cash in on this massive economic opportunity known as 'China'. Yet at the same time, we are also placing pressures upon ourselves, imagining the potential responses of the seemingly all-knowing and all-powerful Party-state to our each and every move. As a 
result, it remains unclear whether the primary issue is in fact censorship, or self-censorship, and where we can begin to draw the line between the two.

The heavy pressures faced by international academics seem quite trivial when compared to the escalating abuses within China. Over the past year, China's first Nobel Peace Prize Laureate Liu Xiaobo died under the state's watch. In the 28 years that passed between 1989 and his death, Liu spent altogether nearly 14 years in prison for his writing and political activism.

In May 2018, Tashi Wangchuk, a Tibetan businessman who promoted the preservation of the Tibetan language, was sentenced to five years in prison for 'inciting separatism'. Tashi's crime had been to speak to the New York Times, and to propose education in Tibetan language for Tibetan people.

Elsewhere, hundreds of thousands of Uyghurs in Xinjiang are being held in 're-education camps'. Among those detained are Uyghur professor and poet Abdulqadir Jalaleddin of Xinjiang Pedagogical University, who has disappeared into this reeducation network since January. And among those who have died in the camps are Islamic scholar Muhammad Salih Hajim, who translated the Quran from Arabic to Uyghur.

Here we see all too direct pressures from the Party-state: there is no blurred line between censorship and self-censorship. People are not delaying publications or worrying about visa denials. They are facing imprisonment and even death simply for speaking their minds and doing what they do: for exercising some of the most basic rights that we increasingly take for granted in our self-censorship.

When we take into consideration the sheer extent of these sacrifices ongoing in China today, the desire of academics outside of China to stay on the authorities' 'good side' and avoid potential visa problems is, to put it bluntly, the epitome of narcissistic self-absorption.

No young idealist began their academic career hoping to trade silence on concentration camps in exchange for visa access. And yet there are of course many pseudo-nuanced ways in which people are able to disguise such narcissistic self-absorption as theoretical sophistication. It has, for some reason, always been cooler to criticise Israel than to criticise China; easier to rally to 
For enthusiasts of cultural relativism,

China has its own path of political development based in its cultural traditions. Who are we to judge? Yet if one really believes this, when exactly is it acceptable to begin to judge?

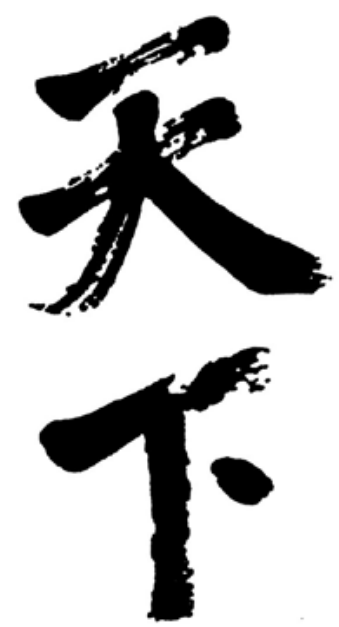

The characters for the phrase tianxia meaning 'everything under the heavens", i.e. the world. the Palestinian cause than to the Uyghur cause, even as camps are being built and filled with living beings. How did this come to be?

For enthusiasts of Marxist theory, China still indulges in its fair share of flowery Marxist rhetoric. To believe this is of any value, one of course has to repress the fact that from the start this has been nothing but ideological window-dressing for an oppressive state that denies its citizens even the most basic of human rights. And yet Marxism often fails to bridge this founding gap between theory and practice.

For enthusiasts of postcolonial theory, China had its century of humiliation and its experience of being semi-colonised. China now may even aspire to rewrite the world order under the harmonious concept of tianxia-how refreshing! Yet to believe this, one has to repress the fact that China has in the modern era implemented a massive colonial project on its borders in Mongolia, Xinjiang, and Tibet, and remains today an expansionist power determined to occupy the South China Sea and democratic, self-governing Taiwan. And yet, much postcolonial theory continues to reify and indeed fetishise 'the West' as the source of all colonial practices, overlooking the horrors of Sinitic colonisation.

For enthusiasts of cultural relativism, China has its own path of political development based in its cultural traditions. Who are we to judge? Yet if one really believes this, when exactly is it acceptable to begin to judge? If one's worldview precludes critique of the construction of a network of concentration camp where people are being held arbitrarily and indefinitely solely based on their ethnicity or religion, dressing this up instead as a 'meritocracy', this would seem to me to be a very dangerous worldview.

Regardless of whether it is fashionable, and regardless of whether it is convenient, it has become increasingly apparent that one cannot conduct research or write on China today without touching on fundamental questions of moral culpability.

As the political system tightens, as academic restrictions increase, as ever more writers and activists face ever longer prison sentences, and as camps are built and filled with living, breathing, thinking human beings, we are no longer in comfortable territory. Rather than worrying about our next ten-year visa, we all need to be more critically reflective on the ways in which our behaviour and collaboration contributes to the perpetuation of a system that does great injustices on a massive scale. 
This is why I, along with colleagues, have proposed a new exercise similar to Australia's 'acknowledgement of country' ritual known as the Xinjiang pledge. At the start of public talks, regardless of location, one acknowledges the distressing rights situation in China today, focussing in on a point of particular concern for the speaker. It may seem ridiculously simple. Yet by acknowledging this discomfiting situation, often so far removed from the comfortable space of the public lecture, thoughts will at least temporarily be moved to this other far too often unthought context and awareness will be enhanced.

Yet most importantly, simply by talking about these matters openly, and attempting to give a voice to those who are unable to speak, the suffocating cycle of silence, to which far too many of us have been accomplices at the nexus of censorship and self-censorship, will ever so slowly be broken. 